\title{
Development of air conditioner split R32 trainer learning media in cooling and air conditioning engineering courses
}

\author{
Fitria Wahyu Ningsih * iD, Ilham Akbar Darmawan (D, Mohammad Fatkhurrokhman \\ Universitas Sultan Ageng Tirtayasa. \\ * Corresponding Author. Email: hertatimukadimah.2019@student.uny.ac.id
}

\section{ARTICLE INFO}

\section{Article History}

Received:

18 August 2021;

Revised:

13 November 2021;

Accepted:

19 November 2021;

Available online:

22 November 2021

\section{Keywords}

Learning media;

Refrigeration;

Research and

Development (R\&D);

SAM Model

\begin{abstract}
This study aims to develop learning media for AC Split R32 in the subject of refrigeration and air conditioning engineering. The method used Research and Development (R\&D), the model of research used is Successive Approximation Models 1 (SAM). The model goes through iteration 1 (Evaluate 1, Design 1, Develop 1), iteration 2 (Evaluate 2, Design 2, Develop 2), and iteration 3 (Evaluate 3, and product implementation). The data collection method uses instruments in the form of observations, interviews, literature studies, and questionnaires that use a Likert scale for measurement the instrument. Based on the research analysis results, media trainers get an average of 76 in the "Very Eligible" category. Then the material results get an average of 63.5 which states that job sheets are in the "Very Eligible" category. Meanwhile, for the feasibility test on 30 student respondents, an average of 71.8 was obtained in the "Very Eligible" category. Meanwhile, based on the performance practice assessment, the average result was 83.4 out of 10 students who practiced in the "Good" assessment category. Thus, based on the development research, the trainer and job sheet can be used as learning media.
\end{abstract}

This is an open access article under the CC-BY-SA license.

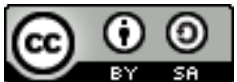

\section{How to cite:}

Ningsih, F. W., Darmawan, I. A., \& Fatkhurrokhman, M. (2021). Development of air contioner split

R32 trainer learning media in cooling and air conditioning engineering courses. Jurnal Pendidikan

Vokasi, 11(2), 213-222. https://doi.org/10.21831/jpv.v11i3.43244

\section{INTRODUCTION}

Education continues to develop. The development of education is related to learning, one of which is at the universities. Learning in universities is very diverse. It is characterized by the use of varied learning media to improve the quality of learning in class. One of these developments is the development of a new curriculum 2019 in the Electrical Engineering Vocational Education Study Program, Faculty of Teacher Training and Education, Sultan Ageng Tirtayasa University. The study program supports the achievement of student competencies through new courses held for the next few years.

Electrical Engineering Vocational Education Study Program is to produce graduates as prospective electrical engineering educators in the field of electrical engineering learning. Relevant skill programs for prospective teachers who graduate from the Electrical Engineering Vocational Education Study Program are electrical engineering and electronic engineering. Meanwhile, there are other skill competencies, namely refrigeration and air conditioning techniques. Competence in this field is in accordance with the curriculum in the electrical engineering expertise program. The 
competency studies several materials such as refrigeration systems and installations, air conditioning systems and installations, automatic control systems, and air conditioning cooling controls.

The existence of refrigeration and air conditioning engineering courses does not exist without reason. Based on data from the Ministry of Education and Culture of the Republic of Indonesia in 2019, there were 75 vocational schools opening refrigeration and air conditioning engineering expertise competencies throughout Indonesia. The development of these expertise competencies makes the government cooperate with PT. Daikin Air Conditioning focuses on air conditioning. The collaboration aims to improve the competence of prospective graduates of students in vocational high school (VHS). In addition, with the large number of vocational students taking these skills, there is a need for prospective teachers from vocational education to improve their quality and competence in refrigeration engineering courses.

Achievement of competencies that must be possessed in the Split AC installation, namely carrying out work such as: 1.) Installation of outdoor and indoor split residential AC units; 2) Operate vacuum pump machines; 3.) Perform gas charging process; 4.) Perform gas charging process; 5.) Perform leak inspection process with leaks tester; 6.) Running outdoor unit test; 7.) Running indoor unit test. While the achievement of competence in maintenance and repair of Split AC, namely: 1.) Maintaining and repairing refrigeration/air conditioning equipment for households; 2.) Replacing electrical and mechanical components in the AC system; and 3.) Repairing damaged parts and components of the cooling system. With the implementation of the IQF-based curriculum, vocational education prepares qualified human resources and is able to be competitive in the global era.

Learning is a process that a person does with the help of teachers to get behavior change (Pane et al., 2017). Learning includes both an aspect of how something is learned and about an aspect of what is learned (Emanuelsson \& Sahlström, 2008). However, practice-oriented learning in higher education certainly aims to integrate theory and practice (Helle et al., 2006). That way, all components like teachers, students, goals, materials, methods, tools, and evaluation must be used in the learning process activities. If one component is not used, then learning will not be effective (Pane et al., 2017). Vocational learning is integrating constructivism theory and evaluation theory into development content and materials to produce material that meets the requirements for vocational students (Mustapa et al., 2015). Skill-based competencies are expected to retain competent and workready graduates and reduce unemployment. So that vocational learning pays attention to aspects of individual skills (Ulum \& Suharno, 2019). Pavlova (2009) stated that the traditional goal of vocational education, in general, is to prepare graduates for direct employment. This vocational education should provide training that is to achieve specific competencies based on the instructor's instructions, emphasize knowledge of certain industrial sectors and contain certain skills or tricks of the trade. According to Lindberg (2003), learning vocational education, apart from being a practice of manual work, is also both a reading practice and a communicative practice.

Achieving competence in the installation of Split AC certainly requires more practice than theory. Learning activities in the Electrical Engineering Vocational Education Study Program prioritize students mastering theory and professional practice skills. To support the learning process in these subjects, a media called learning media is needed. Learning media is a form of intermediary in the learning process that begins by distributing messages in the form of facts or material content from the message giver or lecturer to the recipient of the message or students. In the learning environment that is usually found in vocational education, generally using media trainers or teaching aids.

According to Parwata and Sudiatmika (2020), tools in learning are considered indispensable because of limited human abilities, especially on material topics that require teaching aids to describe them, especially in abstract learning materials such as human digestion, electricity, and others. Practice-based learning and improvement lend themselves to observing learners over time, which allows for conclusions to be drawn during the many episodes in which they exhibit self-directed behavior (Burke et al., 2014). Based on the level of inclination, practice facilities have a very high category so that they can support learning well (Aini \& Sudira, 2015). Learning tools or media can be in the form of people, living things, objects, and everything that can be used by the teacher as an intermediary to present learning materials (Pane et al., 2017). The trainer is a set of tools in the 
laboratory used as an educational medium, a combination of work models and mock-ups (Hasan, 2013).

The air system is an integral part of the refrigeration system to work efficiently so that it can provide hermetic capabilities such as water vapor, non-condensable gases, and other impurities so that they are not controlled at low levels (Ministry of Education and Culture of the Republic of Indonesia, 2014). Air conditioners are usually found for residential purposes (residential systems). The system requires a simple control system, namely a manual switch combined with a room thermostat and a timer switch to control the room temperature (Widodo \& Hasan, 2008). Air conditioning units may be subject to renewal based on economic service life only, useful life only, or either economic service life or useful life when they are close to each other (Takakusagi, 2021).

A split system is a DX system in which the evaporator and condenser are separated and placed in different locations. Typically, the compressor is located near the condenser (Grondzik, 2007). The use of this Split type of air conditioner usually uses a type of refrigerant that speaks and can make the ozone layer thin rapidly from day to day. If previously the use of Split AC in households used refrigerants that were harmful to the environment, the government has now arranged for all these types of air conditioners to switch to using refrigerant R-32 which is more environmentally friendly. It also needs to be applied to learning with this type of AC.

Based on the problems that exist in the Electrical Engineering Vocational Education Study Program, it can be explained as follows, firstly, the unavailability of teaching aids as learning media for cooling and air conditioning techniques, thus indicating the absence of other learning media that can be used. Second, students will find it difficult to achieve the competencies that must be possessed practically in the installation of Split AC because they cannot directly know the components to be installed. Third, students will find it difficult to carry out maintenance and repair of Split AC without real experimentation with AC. Fourth, students cannot demonstrate the installation of Split AC easily and efficiently without learning media such as trainers. Fifth, the many uses of conventional Split $\mathrm{AC}$ that do not use R32 refrigerant so that it can harm the environment.

Based on the description of the problem above, it is necessary to develop a unit in the form of a cooling trainer as one of the teaching and learning process supporters. Thus, a research entitled development of Split R32 Air conditioning trainer was conducted in the air conditioning and air conditioning engineering course to answer these problems.

\section{RESEARCH METHOD}

The research to be carried out is a type of development research. The researcher developed a learning media in the form of a Split R32 AC trainer in the cooling and air conditioning engineering course in Electrical Engineering Vocational Education Faculty of Teacher Training and Education, Universitas Sultan Ageng Tirtayasa using the SAM (Successive Approximation Model) development model. The SAM model provides a clear stage for successful media development as a benchmark for completing and targeting everything in a fast time to achieve results. The first model of SAM is very effective and suitable for a product in an uncomplicated small study (Allen \& Sites, 2012). The stages or cycles of the Successive Approximation Model can be seen in Figure 1.

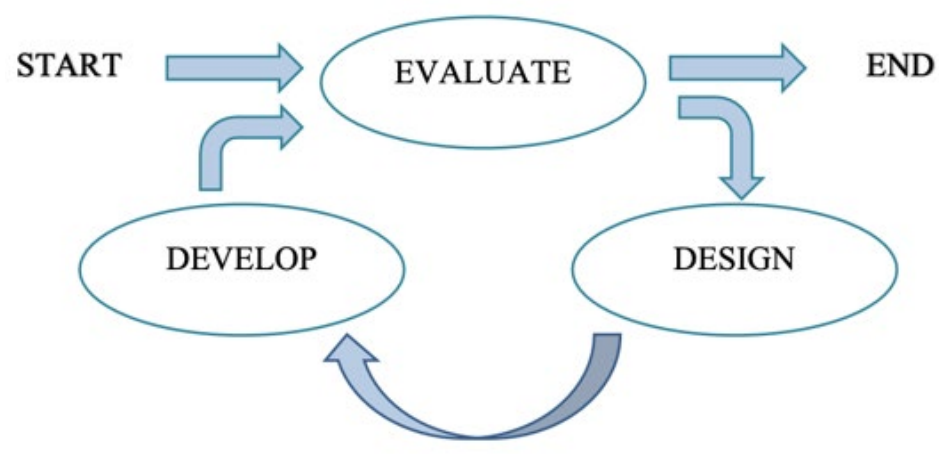

Figure 1. Successive Approximation Stage Model 1 (SAM 1) (Allen \& Sites, 2012) 
This research was conducted in the Vocational Education Electrical Engineering Study Program in Faculty of Teacher Education and Science Education, Sultan Ageng Tirtayasa University, with Ciwaru Raya Street, Cipare, Serang districts, Serang City, Banten 42117, Indonesia. The subject of this research is fourth semester student.

The research instrument used in the research consists of the observation, interview, questionnaire, and practice assessment sheet. Observation is a data collection technique used to observe and find facts in the field. Questionnaires were used to collect data on expert judgment validation and college student responses. The expert judgment is two instructors who are experts in refrigeration and one technician who is an expert in the air conditioner. The student work assessment sheet involves ten semesters 4 or 2019 batch students to test the feasibility of the Split AC trainer tool. The system used by the researcher is to conduct a practicum experiment on each job sheet with ten students to test the trainers and the job sheets that are tested for each job.

The observation was carried out at the electrical engineering education laboratory of the Universitas Sultan Ageng Tirtayasa. The availability of tools and materials in the manufacture of trainers in the laboratory indicates that there are already split type AC components that can be used in making trainers, but the other supporting components are not yet available. The grid diagram for observations in the laboratory can be seen in Table 1.

Table 1. Grid For Observation Sheet

\begin{tabular}{ll}
\hline No. & Aspect \\
\hline 1 & Learning media in Laboratory \\
2 & Size of the laboratory \\
3 & Componen of AC Split \\
4 & Componen of AC Split Instalation \\
5 & AC trainer in the laboratory \\
6 & AC Split jobsheet \\
7 & AC Split Manual book \\
8 & Trainer for refrigeration engineering courses \\
9 & Size of Trainer \\
\hline
\end{tabular}

The Interview is conducted as reinforcement from direct observations so that the basis for problems in the laboratory of the electrical engineering education with head of laboratory. Based on the results of the interview summary, it can be concluded that the laboratory needs to have learning media as a support for practical learning. The AC Split R32 trainer learning media is made, which can be used for students' studies. The questionnaire instrument for material experts is given to the media expert to obtain an assessment and feedback on the AC Split trainer. The instrument grid for media experts can be seen in Table 2 .

Table 2. Grid For Media Expert

\begin{tabular}{lll}
\hline No. & Aspect & Question Number \\
\hline 1 & Display \& Size & $1-8$ \\
2 & Media Coloring & $9-12$ \\
3 & Media Writing & $13-16$ \\
4 & Technical Quality & $17-22$ \\
\hline
\end{tabular}

The questionnaire instrument for a material expert is given to the material expert to obtain an assessment and feedback on the content of the material in order to remain relevant to the developed learning medium. The instrument grid for material experts can be seen in Table 3.

Table 3. Grid For Media Expert

\begin{tabular}{lll}
\hline No. & Aspect & Question Number \\
\hline 1 & Relevant to curriculum & $1-4$ \\
2 & Contents & $6-12$ \\
3 & Instructional Quality & $13-20$ \\
\hline
\end{tabular}


The questionnaire instrument for feasibility for the respondent is given to the college student in the fourth semester. The instrument grid for material experts can be seen in Table 4 .

Tabel 4. Grid For Respondent

\begin{tabular}{lll}
\hline No. & Aspect & Question Number \\
\hline 1 & Learning design & $1-10$ \\
2 & Communication for user & $11-20$ \\
\hline
\end{tabular}

The answer choice assessment table in the questionnaire consists of strongly agree (SS), agree (S), TS (disagree), and strongly disagree (STS) (Sugiyono, 2016), as can be seen in Table 5.

Table 5. Scale of Questionnaire

\begin{tabular}{lll}
\hline No. & Scale & Scoring \\
\hline 1 & SS & 4 \\
2 & S & 3 \\
3 & ST & 2 \\
4 & STS & 1 \\
\hline
\end{tabular}

To determine the conclusions from the results that have been achieved, criteria are set as can be seen in Table 6.

Table 6. Category of Eligibility

\begin{tabular}{lll}
\hline No. & Score & Eligibility Level \\
\hline 1 & $\mathrm{X}>\mathrm{X}+1 . \mathrm{Sbx}$ & Very Worthy \\
2 & $X+S b x>X>X$ & Worthy \\
3 & $X \geq x-1 . S B x$ & Not Feasible \\
4 & $\mathrm{X}<X+1 . S b x$ & Very Inappropriate \\
\hline
\end{tabular}

\section{RESULT AND DISCUSSION}

Based on the results of observations and interviews at the Electrical Engineering Vocational Education Laboratory conducted on Friday, October 2, 2020, it is known that there are no trainers for the R32 Split AC Refrigeration and Air Conditioning Engineering course, job sheets, and manuals. The learning objectives for this type of practical learning on Split AC type air conditioners are based on the 2016 SKKNI's list of Competency Units for Air Conditioning (AC) types of split AC type expertise.

The initial stage is to make an initial tool display design that aims to determine the shape and placement of components correctly, referring to the initial analysis, namely the efficiency of the shape of the tool so that it can be placed easily. To design shapes and layouts using the CorelDraw 2019 application. Here you can see the results of the initial shape design in Figure 2.

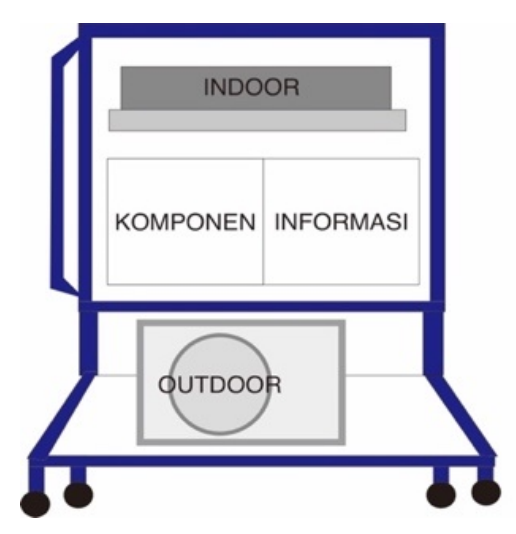

Figure 2. Desain of Iron Frame to Place the Component 
The next step is to install the acrylic board on the iron frame that has been painted, then finish the installation of the components on the product and test each component whether it is good and correct. Furthermore, after the components are installed, and the electrical system behind the frame is installed, the trainer can be tested. Tests are also carried out to test whether the board and iron frame are strong enough to support, then test the performance of the indoor unit, test the performance of the outdoor unit, electrical system, and piping. Furthermore, testing is carried out with each practicum trial job. The results of the assembled AC Split R32 trainer can be seen in Figure 3 .

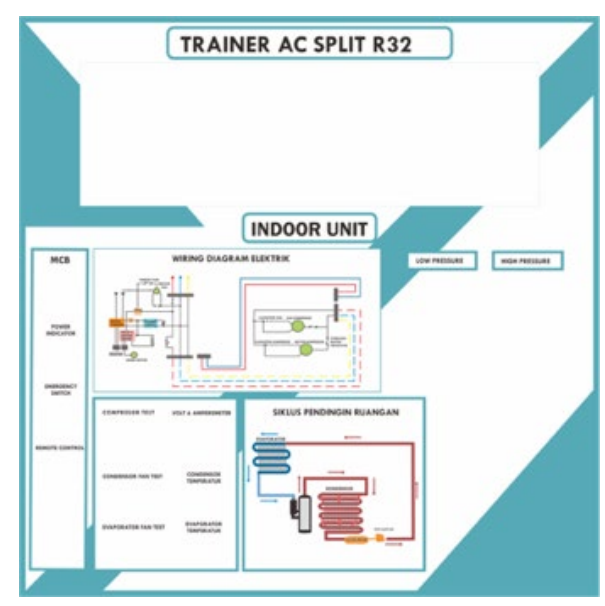

Figure 3. Desain of Layout

The next step in making the job sheet begins with looking for material from book sources as an introduction to AC Split. Researchers got five basic materials as follows: 1.) Material about Split AC Components; 2.) Material about electrical installation and piping in Split AC; 3.) Material about Service and cleaning of indoor units; 4.) Material about Vacuum in Split AC; 5.) Material Refrigerant R32 in Split AC unit; and 6.) Replacing electrical components. After getting the basic material, the researcher made the contents of the material and instructions in accordance with the previously designed competencies.

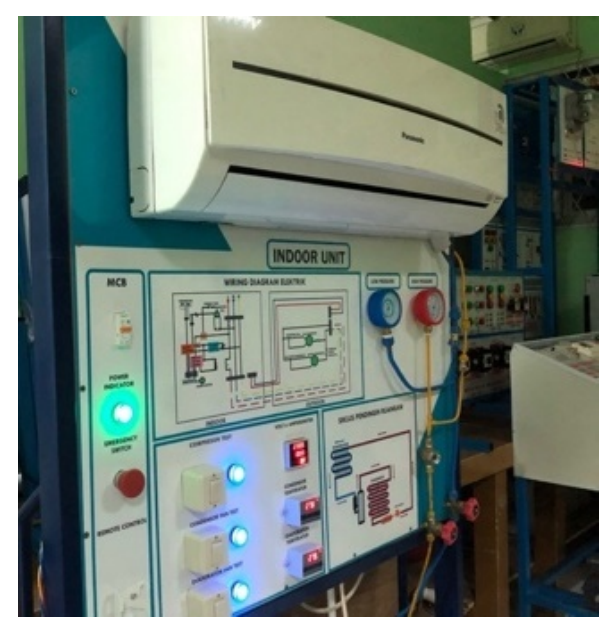

Figure 4. Trainer AC Split R32

Data validation media obtained from media experts used to get an Assessment of the aspect for the conclusion of validation of media, and material experts can be seen in Figure 5. 


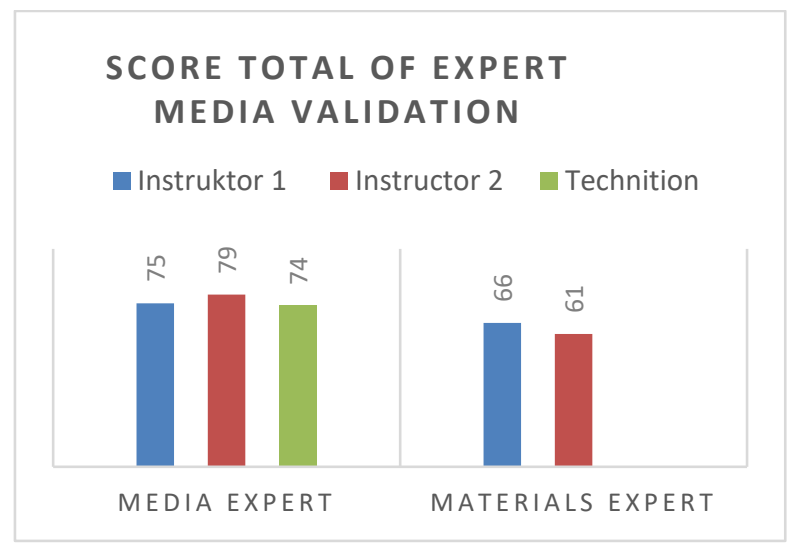

Figure 5. Graphic Expert Validation

Table 7. Conversion Table of Category of Eligibility Media Expert

\begin{tabular}{llll}
\hline No. & Score & Score Range & Eligibility Level \\
\hline 1 & $\mathrm{X}>\mathrm{X}+1 . \mathrm{Sbx}$ & $x \geq 88$ & Very Worthy \\
2 & $x+S b x>x>x$ & $71>x \geq 88$ & Worthy \\
3 & $x \geq x-1 . S B x$ & $55>x \geq 88$ & Not Feasible \\
4 & $x<x+1 . S b x$ & $x<44$ & Very Inappropriate \\
\hline
\end{tabular}

Table 8. Conversion Table of Category of Eligibility Materials Expert

\begin{tabular}{llll}
\hline No. & Score & Score Range & Eligibility Level \\
\hline 1 & $\mathrm{X}>\mathrm{X}+1 . \mathrm{Sbx}$ & $x \geq 80$ & Very Worthy \\
2 & $x+S b x>x>x$ & $71>x \geq 50$ & Worthy \\
3 & $x \geq x-1 . S B x$ & $55>x \geq 80$ & Not Feasible \\
4 & $x<x+1 . S b x$ & $x<44$ & Very Inappropriate \\
\hline
\end{tabular}

Table 9. Conversion Table of Category of Eligibility Respondents Expert

\begin{tabular}{llll}
\hline No. & Score & Score Range & Eligibility Level \\
\hline 1 & $\mathrm{X}>\mathrm{X}+1 . \mathrm{Sbx}$ & $x \geq 80$ & Very Worthy \\
2 & $x+S b x>x>x$ & $71>x \geq 50$ & Worthy \\
3 & $x \geq x-1 . S B x$ & $55>x \geq 80$ & Not Feasible \\
4 & $x<x+1 . S b x$ & $x<44$ & Very Inappropriate \\
\hline
\end{tabular}

Based on the results of the average assessment of the two media experts, it was 76, with a total score of 120 answers. So that was within the score range $\mathrm{x}<88$. So based on the data, it means being in the "Very Eligible" eligibility category. Thus, the AC Split R32 trainer job sheet product from all aspects states that it is very suitable for the AC Split R32 trainer to use as a learning medium. Based on two materials experts, a total score of 127 was obtained and from the average assessment results obtained a value of 63.5 , so that the score is in the score range $\mathrm{x}<80$, so that the feasibility results have the meaning of being in the "Very Eligible" eligibility category. Thus, the AC Split R32 trainer job sheet product from all aspects states that it is very suitable for the AC Split R32 trainer to use as a learning medium.

Based on the calculation, the total score of the answers is 2154 , the average result of the assessment of the 30 student respondents is 71.8 , so that based on the table that is in the score range $\mathrm{x}<80$ so that the feasibility results are based on the score range means being in the "Very Eligible" eligibility category. Thus, the product is very suitable to be used as a learning medium. Based on the results, it was found that students who had demonstrated using the trainer and using job sheet were able to do so with an average score of 83.4 from the total maximum score of 100 . So based on the results of the analysis of existing data, it shows that practical learning is in the psychomotor category at the student falls into the "Good" category. Thus, during practical experiments using trainers and 
student worksheets is helped to achieve competence. Thus, these results mean that the trainer can be used properly so that students get good scores according to their existing competencies.

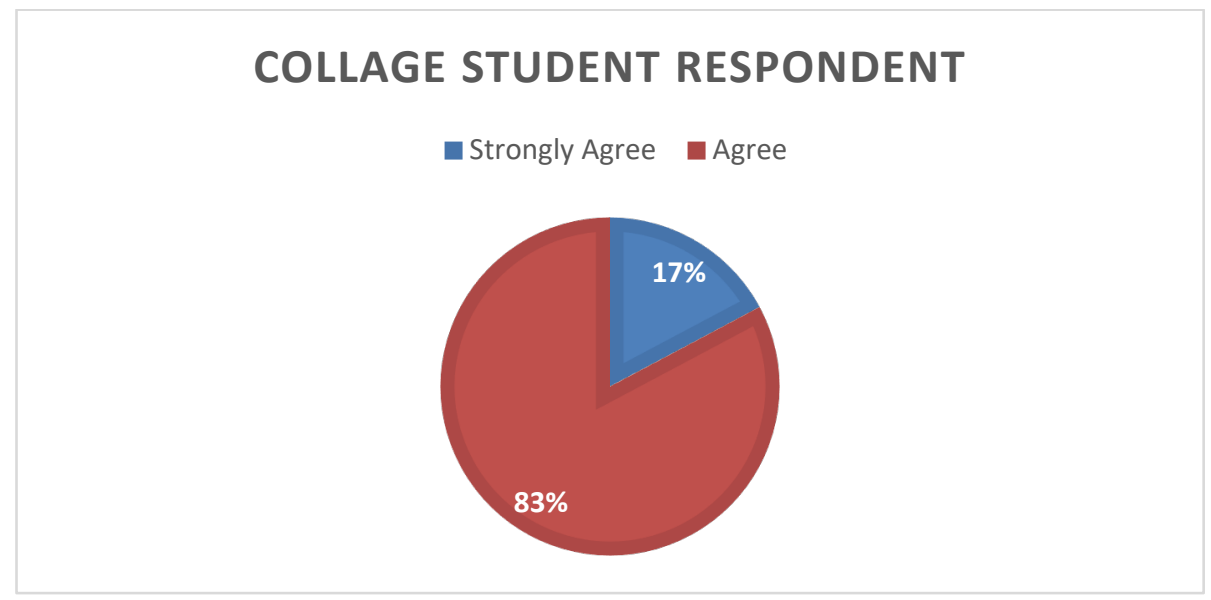

Figure 6. Diagram of Total Student Respondents Answering

Discussion

The subject of refrigeration and air conditioning engineering is currently a subject to understand the principles of cooling systems such as air conditioners, in the development of learning media that has been carried out in the form of split AC trainer kits, job sheets, and manual books which are improvements to the trainers that have been developed previously. In addition, the results of this development take into account the advantages and disadvantages of previous studies.

Based on research Adityawarman (2018), this research was motivated by the lack of AC trainer learning media in refrigeration engineering courses. The drawbacks of the media trainer are a less minimalist form, not using a digital system, lack of learning equipment, and the absence of job sheets and manuals. As a result, the media can be used to study the basic components of the air conditioner. From this research, the author develops learning media that is equipped with an attractive and minimalist form accompanied by a digital system and complete learning support equipment.

Further research was carried out by Sudarsono (2018) with the title Level feasible media learning system Air Conditioner (AC) to increase learning result. This research is motivated by the use of learning media in boring subjects and does not increase competence. The result of this research is a learning teaching aid product in the form of a table with a top board containing an explanation image of the components with the results of the feasibility of the product being said to be feasible and can be used as a learning media. Based on this research, the media that has been developed adapts the idea by providing an explanation image of the components on the split ac trainer media. In addition to the explanation of the components, it is added by explaining the cooling system workflow that makes it look interesting and easier for users to learn from the media.

Further research was carried out by Wirawan and Widjanarko (2020) with the title making split AC teaching aids as learning media for cooling system courses. The problem with this research is that the number of teaching aids in the cooling system course is less than the number of students who use them. This research focuses more on teaching aids related to machines so that the props are made very simple with the main components of split ac without any additions. From this research, the researcher developed the parts on the main components and the development of supporting components in learning. In addition, it also prioritizes electrical learning over machines. That way, the refinement of the trainer tool is made attractive, the components are complete, and provide supporting media such as worksheets.

The making of learning media following the revised 2019 curriculum with competency guidelines is obtained through the syllabus for refrigeration and air conditioning engineering courses based on the SKKNI in the field of Split-type AC refrigeration engineering skills. Based on the list of Competency Units for the Air Conditioning Industry (Air Conditioner/AC) SKKNI in 2016 expertise in the type of split AC. 
According to Hasan's (2013) theory, trainers can be used to achieve competencies because the trainer can be used for training in understanding practice work as happens in the industry. In addition, with that equipment in trainer AC Split R32, the interaction between the teacher and the student can be minimized. So that the teacher can act as a facilitator and the student can understand well with independent or team learning using the provided worksheets and manual books of AC Split R32 Trainer Media. After knowing the feasibility of the AC Split trainer, the results were obtained with the distribution of questionnaires to BBPLK instructors and on a limited scale to be distributed to 30 students. The data show that Based on the results that "Very Eligible." This is, of course, due to the advantages of developing this trainer.

The split AC trainer learning media has advantages compared to previous research, including this split AC trainer learning media can help increase students' competence in the field of air conditioning, Split AC trainer learning media increases student learning motivation, media trainer is very minimalist and easy to push and place, media trainer can be easily disassembled, AC Split trainer learning media can help lecturers in providing practical learning in refrigeration, and air conditioning engineering courses, This trainer learning media has a learning job sheet making it easier to do practical learning, and this media trainer has a user manual so that the user can understand the function and know the specifications of each component.

\section{CONCLUSION}

Based on the result of research and development can be summarized as follow: 1.) Development of the Split R32 AC trainer that can be used and can be operated properly. The research and development method used is Research and Development using the Successive Approximation 1 development model with the Evaluation, Design, and Development stages. The stages of the product manufacturing process start into three stages with six steps: (1) To analyze the initial situation, needs, and goals; (2) Design; (3) Developing the layout and the installation of components; (4) The second stage is evaluating the results and making revisions; (5) Design revision; and (6) Final finishing of AC Split trainer with the size $105 \mathrm{~cm}(1) \times 180 \mathrm{~cm}$ (h) along with the job sheet and manual book, feasibility testing and product implementation; 2.) Based on the results, the feasibility test of media experts got an average point of 76 in the "Very Eligible" category. The feasibility test from material experts got the average point 63.5 "Very Eligible" category. The Feasibility Test of respondents from 30 students got an average point of 71.8 in the "Very Eligible" category. Meanwhile, the Performance Practice Assessment from 10 students who did practical trainer and job sheet got an average result of 83.4 in the "Good" category.

Based on the results of the research and development of the AC Split R32 trainer kit learning media that has been carried out, there are several suggestions for the use of this trainer learning media development product. Further suggestions from researchers are as follows: 1.) This Split AC Trainer has parts made of iron, so it requires caution in its use; 2.) The material in the worksheet can be developed and added back further and in-depth; and 3.) This Split AC Trainer has a maximum current limit that is in accordance with the nameplate to avoid compressor damage.

\section{REFERENCES}

Adityawarman, A. (2018). Trainer pendingin ruangan menggunakan AC Split R32 ramah lingkungan sebagai media pembelajaran mata kuliah teknik refrigasi dan tata udara di Universitas Negeri Semarang. Edu Elektrika Journal, 7(2), 27-34. https://doi.org/10.15294/eej.v7i2.29139

Aini, S. N., \& Sudira, P. (2015). Pengaruh strategi pembelajaran, gaya belajar, sarana praktik, dan media terhadap hasil belajar patiseri SMK se-Gerbangkertasusila. Jurnal Pendidikan Vokasi, 5(1), 88-102. https://doi.org/10.21831/jpv.v5i1.6077

Allen, M., \& Sites, R. (2012). Leaving ADDIE for SAM: An agile model for developing the best learning experiences. American Society for Training \& Development Press. 
Burke, A. E., Benson, B., Englander, R., Carraccio, C., \& Hicks, P. J. (2014). Domain of competence: Practice-based learning and improvement. Academic Pediatrics, 14(2), S38-S54. https://doi.org/10.1016/j.acap.2013.11.018

Emanuelsson, J., \& Sahlström, F. (2008). The Price of Participation: Teacher control versus student participation in classroom interaction. Scandinavian Journal of Educational Research, 52(2), 205-223. https://doi.org/10.1080/00313830801915853

Grondzik, W. T. (2007). Air-conditioning System Design Manual (2nd ed.). Elsevier.

Hasan, S. (2013). Analisis perakitan trainer unit berdasarkan aplikasi konsep refrigerasi pada mata kuliah sistem pendingin. https://www.academia.edu/download/57045202/anzdoc.com_analisis-perakitan-trainerunit-berdasarkan-aplika.pdf

Helle, L., Tynjälä, P., \& Olkinuora, E. (2006). Project-based learning in post-secondary educationtheory, practice and rubber sling shots. Higher Education, 51(2), 287-314. https://doi.org/10.1007/s10734-004-6386-5

Kementerian Pendidikan dan Kebudayaan Republik Indonesia. (2014). Sistem dan instalasi udara 4. Kementerian Pendidikan dan Kebudayaan Republik Indonesia. https://nos.jkt1.neo.id/bse/perpustakaan/2/2183_2056.pdf

Lindberg, V. (2003). Learning practices in vocational education. Scandinavian Journal of Educational Research, 47(2), 157-179. https://doi.org/10.1080/00313830308611

Mustapa, M. A. S., Ibrahim, M., \& Yusoff, A. (2015). Engaging vocational college students through blended learning: Improving class attendance and participation. Procedia - Social and Behavioral Sciences, 204, 127-135. https://doi.org/10.1016/j.sbspro.2015.08.125

Pane, A., Dasopang, M. D., \& Setiawan, A. (2017). Belajar dan pembelajaran. FITRAH: JURNAL KAJIAN ILMU-ILMU KEISLAMAN, 3(2), 333-352. https://doi.org/10.24952/fitrah.v3i2.945

Parwata, K. Y. L., \& Sudiatmika, A. A. I. A. R. (2020). The effectiveness of learning tools in science learning. Journal of Physics: Conference Series, 1503, 12049. https://doi.org/10.1088/1742$6596 / 1503 / 1 / 012049$

Pavlova, M. (2009). The vocationalization of secondary education: The relationships between vocational and technology education. In R. Maclean \& D. Wilson (Eds.), International Handbook of Education for the Changing World of Work (pp. 1805-1821). Springer. https://doi.org/10.1007/978-1-4020-5281-1_122

Sudarsono, B. (2018). Level feasibility media learning system Air Conditioner (AC) to increase learning result. Jurnal Taman Vokasi, 6(1), 18-24. https://doi.org/10.30738/jtv.v6i1.2816

Sugiyono, S. (2016). Metode Penelitian Kuantitatif, Kualitatif, dan R\&D. Alfabeta.

Takakusagi, A. (2021). Theoretical study evaluating renewal of an air-conditioning system. Journal of Building Engineering, 44, 102876. https://doi.org/10.1016/j.jobe.2021.102876

Ulum, A. Z., \& Suharno, S. (2019). Infiltrasi budaya global terhadap budaya lokal pesta Baratan dalam mempengaruhi pembentukan budaya kewargaan. Harmoni Sosial: Jurnal Pendidikan IPS, 6(2), 137-144. https://doi.org/10.21831/hsjpi.v6i2.10023

Widodo, S., \& Hasan, S. (2008). Sistem refrigerasi dan tata udara. Direktorat Pembinaan Sekolah Menegah Kejuruan Republik Indonesia.

Wirawan, M. A., \& Widjanarko, D. (2020). Pembuatan alat peraga AC Split 1 PK sebagai media pembelajaran mata kuliah sistem pendingin di Universitas Negeri Semarang. Journal of Mechanical Engineering, 9(1), 58-63. https://journal.unnes.ac.id/sju/index.php/jmel/article/view/34034 